„Kwartalnik Filmowy” nr 109 (2020)

ISSN: 0452-9502 (Print) ISSN: 2719-2725 (Online)

https://doi.org/10.36744/kf.28o

(C) Creative Commons BY-NC-ND 4.0

Katarzyna Uchowicz

Instytut Sztuki Polskiej Akademii Nauk

https://orcid.org/OOOO-0002-4844-5629

\title{
Projektanci czasoprzestrzeni. Modernistyczna architektura w kadrze filmowym
}

\author{
Slowa kluczowe: \\ modernizm; \\ architektura XX w.; \\ Praesens; \\ czasoprzestrzeń; \\ synteza sztuk; \\ reżyseria ruchu
}

\begin{abstract}
Abstrakt
Autorka omawia wybrane przykłady przenikania się architektury i filmu w dwudziestoleciu międzywojennym. Punkt wyjścia artykułu stanowi działalność grupy modernistów Praesens, zaś jego celem jest ukazanie modernizmu jako syntezy sztuk oraz interdyscyplinarnych dialogów artystycznych. Filmowo-architektoniczne związki zostały zaprezentowane z różnych perspektyw, począwszy od zaangażowania architektów w projekty scenograficzne (Szymon Syrkus, Andrzej Pronaszko), przez współpracę projektantów z reżyserami (Robert Mallet-Stevens, Marcel L’Herbier), komponowanie fotomontaży, po kształtowanie dekoracji na wzór nowoczesnych miast - i odwrotnie - projektowanie architektury na podstawie wizji scenicznych (Barbara i Stanisław Brukalscy). Relacje architektury i filmu objęły także nowy język architektoniczny, czego przykładem są stosowane przez architektów terminy zaczerpnięte z nomenklatury filmowej, takie jak „reżyseria ruchu” czy „czasoprzestrzeń”, komentowane równocześnie przez włoskiego teoretyka kina Ricciotta Canudo. Ponadto w tekście przypomniano biografie architektów, którzy po uzyskaniu dyplomu poświęcili się wyłącznie scenografii, otwierając tym samym nowe pole działalności zawodowej (Jacek Rotmil).
\end{abstract}

Artykuł powstał na podstawie referatu wygłoszonego podczas III Zjazdu Filmoznawców i Medioznawców („Przestrzenie - praktyki - artykulacje”, Uniwersytet Łódzki, Łódź, 17-19 czerwca 2019 r.). 
Inspiracją do napisania tekstu stała się interdyscyplinarna działalność grupy modernistów Praesens w latach 1925-1939 zogniskowana wokół eksperymentów na polu łączenia sztuk. Awangardowe ugrupowanie pełni tutaj rolę przewodnika po architekturze modernistycznej i jej związkach z filmem. Rzecz dotyczy zarówno architektury zatrzymanej w kadrze filmowym, jak i wykreowanej specjalnie na potrzeby filmu, bądź - co wydaje się bardziej interesujące i mniej oczywiste dla badaczy tropiących zależności pomiędzy projektowaniem przestrzeni a kinematografią - architektury przeniesionej z planu filmowego do realnego świata czy istniejących realizacji architektonicznych pobudzających wyobraźnię reżyserów na tyle, by wywarły one znaczący wpływ na finalny kształt scenariusza. Krzyżujące się wątki architektoniczno-filmowe zostały nakreślone $\mathrm{w}$ wymiarze odpowiadającym obecnemu stanowi badań. Z tego względu struktura tekstu może niekiedy przypominać patchwork o pozornie chaotycznym, ale jednak kontrolowanym wzorze.

\section{Architekci a dekoratorzy}

W okresie dwudziestolecia międzywojennego projekty dekoracji filmowych i teatralnych pozostawały w przeważającym stopniu w gestii architektów. Terminy - takie jak scenografia i scenograf - dopiero się rodziły. Twórców scenicznego imaginarium określano zazwyczaj jako dekoratorów, wskazując raczej pełnioną przez nich funkcję, a nie wyuczoną profesję. Projektowanie dekoracji stanowiło jedną z możliwych aktywności zawodowych po uzyskaniu tytułu architekta dyplomowanego. Zdarzały się jednak przypadki, że architekci zaraz po ukończeniu studiów porzucali projektowanie budynków czy planowanie miast, wiążąc się z wybranymi reżyserami oraz wytwórniami na dłuższy czas bądź na stałe. W środowisku warszawskim lat 30. XX w. monopol na dekoracje określane mianem architektonicznych miała spółka Rotmil \& Norris. Pierwszy z właścicieli, Jacek Rotmil, ukończył architekturę w Karlsruhe, gdzie po uzyskaniu dyplomu krótko pracował w zawodzie architekta wnętrz. Około 1918 r. jako Jacques (lub Jack) Rotmil związał się z berlińskim przemysłem filmowym. Sprawował funkcję dekoratora w filmach oraz sztukach teatralnych reżyserowanych przez m.in. Wilhelma Thielego (Das Modell vom Montparnasse, 1929) i Victora Jansona (Lügen auf Rügen, 1932)1. W 1933 r., po desygnacji Adolfa Hitlera na kanclerza Niemiec, ze względu na żydowskie pochodzenie wyemigrował do Polski. Osiadł w Warszawie, zmieniając imię na Jacek. Pierwszym polskim filmem Rotmila były Dzieje grzechu w reżyserii Henryka Szaro (współpracował z pionierem polskiej scenografii, Józefem Galewskim). W 1934 r. założył spółkę dekoratorską ze Stefanem Norrisem, polskim architektem, absolwentem Politechniki Wiedeńskiej oraz stołecznej Szkoły Sztuk Pięknych. Do wybuchu II wojny światowej duet Rotmil \& Norris przygotował dekoracje i rekwizyty do znakomitej większości rodzimych produkcji filmowych (m.in. do Panienki z Poste Restante/reż. Jan Nowina-Przybylski, Michał Waszyński, 1935/, Rapsodii Bałtyku /reż. Leonard Buczkowski, 1935/, Dybuka /reż. Michał Waszyński, 1937/, Znachora /reż. Michał Waszyński, 1937/), przy których Rotmil pełnił zazwyczaj funkcję kierownika artystycznego. Był także współtwórcą Stowarzyszenia Realizatorów i Techników Filmowych ${ }^{2}$. Architekturą parał się okazjonalnie - w historii przedwojennych warszawskich realizacji "nurtu luksusowego" zapisał się sklep firmy Philips zlokalizowany prawdopodobnie przy ul. Marszałkowskiej $139 \mathrm{w}$ Warszawie, wyróżniający się przeszkloną witryną, neonową reklamą oraz imponującymi drzwiami z chromoniklowanej blachy (proj. Rotmil \& Edward Eber). 


\section{W poszukiwaniu integracji sztuk}

Niemal w tym samym czasie, gdy Rotmil rozpoczynał w Niemczech swoją przygodę z filmem, w Warszawie ukazał się pierwszy numer Kwartalnika Modernistów „Praesens” (1926) inicjujący działalność nowej modernistycznej formacji w stołecznym środowisku artystycznym. Nazwę - tak czasopisma, jak i grupy, której pomysłodawczynią była architektka Helena Syrkus - utworzono od łacińskiego terminu tempus praesens (czas teraźniejszy). Akcentowała ona ambicje kreowania współczesnych działań na niwie architektury oraz plastyki ${ }^{3}$. Pozostawała jednocześnie czytelna poza granicami kraju i błyskawicznie stała się synonimem polskiej awangardy w kręgach międzynarodowych (równocześnie na polskim gruncie sięgano po termin „teraźniejszość”, komentując nowe prądy architektoniczne i artystyczne). Programowy periodyk zawierał przede wszystkim artykuły poświęcone nowoczesnemu kształtowaniu przestrzeni, inspirowane teoriami Le Corbusiera, Kazimierza Malewicza i holenderskiej grupy De Stijl (teksty dotyczące tego tematu redagował Szymon Syrkus) oraz malarstwu (redaktorem prowadzącym był Henryk Stażewski). Kim byli członkowie ugrupowania plasującego się w głównym nurcie stołecznej awangardy? Poza wspomnianymi Szymonem i Heleną Syrkusami tworzyli ją architekci bądź studenci Wydziału Architektury Politechniki Warszawskiej: Bronisław Elkouken, Stanisław Zalewski, Bohdan Lachert, Józef Szanajca, Józef Malinowski oraz plastycy Henryk Stażewski, Katarzyna Kobro, Aleksander Rafałowski, Jan Golus, Karol Kryński, Maria Nicz-Borowiakowa ${ }^{4}$. Ówczesne spectrum działalności formacji anonsowała zamieszczona w pilotażowym numerze "Praesensu” reklama o treści: Architekci i malarze grupy Praesens wykonywuja wszelkie roboty w zakres architektury i malarstwa wchodzace, a więc: projekty parcelacji osiedli podmiejskich; projekt $i$ budowę domów miejskich i podmiejskich wraz z całkowitym urządzeniem i malowaniem wnętrz; projekty i budowę wystaw, sklepów i pawilonów wystawowych; dekoracje teatralne i kinematograficzne, oraz wszelkie prace z zakresu grafiki: układy druk. ogłoszen, reklamy, plakaty, ilustracje, okładki do ksiażek ${ }^{5}$. W tekście reklamowym wspomniano, że grupie można było zlecić wykonanie dekoracji kinematograficznych (teatralnych) oraz projekty plakatów filmowych. Czy rzeczywiście tak było i który z wymienionych twórców mógł takowemu zamówieniu sprostać? Doświadczenie współpracy z przemysłem filmowym miał wówczas jedynie Szymon Syrkus, który po uzyskaniu dyplomu na warszawskim wydziale architektonicznym w 1922 r. ruszył do Europy w poszukiwaniu pracowni, gdzie mógłby odbyć staż i zdobyć praktykę zawodową ${ }^{6}$. Na przełomie lat 1922 i 1923 znalazł zatrudnienie w wytwórni Universum Film Aktiengesellschaft (UFA) w Berlinie jako dekorator i projektant plakatów filmowych. Na obecnym etapie badań nad działalnością architekta trudno jednoznacznie stwierdzić, do jakich konkretnie filmów przygotowywał dekoracje. W $1922 \mathrm{r}$. UFA otworzyła dwa nowe studia - w Neubabelsbergu (dziś Poczdam-Babelsberg) oraz Berlinie Tempelhofie. Zapewne to w jednym z nich pracował Syrkus.

Cztery lata po ukazaniu się pionierskiego numeru czasopisma (anonsowanego wówczas - jak wspomniano - jako kwartalnik) w 1930 r. wydano długo oczekiwany numer drugi, i jak się wkrótce okazało, ostatni. Na okładce, zakomponowanej jak plakat reklamowy, zasygnalizowano znacznie szerszy zakres tematyczny. Dominująca na płaszczyźnie przekraczającej wymiar A4 nazwa „praesens”, złożona krojem pisma zaprojektowanym przez Henryka Stażewskiego, opartym - co było w dwudziestoleciu międzywojennym en vogue - wyłącznie na minuskule, odcinała się od tła, które wypełniły gęsto rozmieszczone $\mathrm{w}$ szpalcie nazwy omawianych $\mathrm{w}$ numerze dyscyplin przedstawione naprzemiennie w językach polskim, francuskim, niemieckim i angielskim. Były to: architektura, malarstwo, 
fotografia, teatr, film i poezja. Pierwszą literę w słowie "architektura” powiększono i wyróżniono kolorem czerwonym (ilustr. 1.). Ten prosty chwyt graficzny stanowił wizualną wykładnię dominacji architektów w strukturze ugrupowania, ale jednocześnie wskazywał na syntezę sztuk w ramach działalności jednej grupy artystycznej. Z punktu widzenia architektów to reprezentowana przez nich dyscyplina miała jednoczyć pozostałe (około 1930 r. zmienił się skład Praesensu, przystali do niego m.in. sympatyzujący wcześniej z formacją Barbara i Stanisław Brukalscy, Anatolia Hryniewicka-Piotrowska i Roman Piotrowski oraz Andrzej Pronaszko). Pogląd, jakoby architektura miała skupiać pozostałe dyscypliny, stał w opozycji do popularnej wówczas koncepcji zmarłego w 1923 r. włoskiego teoretyka kina Ricciotta Canuda. W słynnym manifeście z 1911 r. (Manifeste du septième art) Canudo uznał film za nową dyscyplinę sztuki, początkowo szóstą po Heglowskim kwintecie obejmującym architekturę, malarstwo, rzeźbę, muzykę i poezję, a później siódmą po uwzględnieniu tańca (wymienione dyscypliny nie pokrywały się z wyborem zamieszczonym na okładce drugiego numeru czasopisma „Praesens”). Publikujący we Francji włoski teoretyk definiował kino jako sztuki plastyczne wprawione w ruch, jako jedność rytmu przestrzeni w odniesieniu do sztuk plastycznych i rytmu czasu w kontekście muzyki i poezji oraz jako syntezę wszystkich sztuk. Wkrótce stosowane przez niego wyrażenia "rytm przestrzeni” i „rytm czasu” zastąpiono terminem „czasoprzestrzeń". Koncept ten, określany także jako rytm czasoprzestrzenny, na stałe wszedł do słownika modernistów jako niezbywalny, czwarty wymiar nowoczesnej architektury.

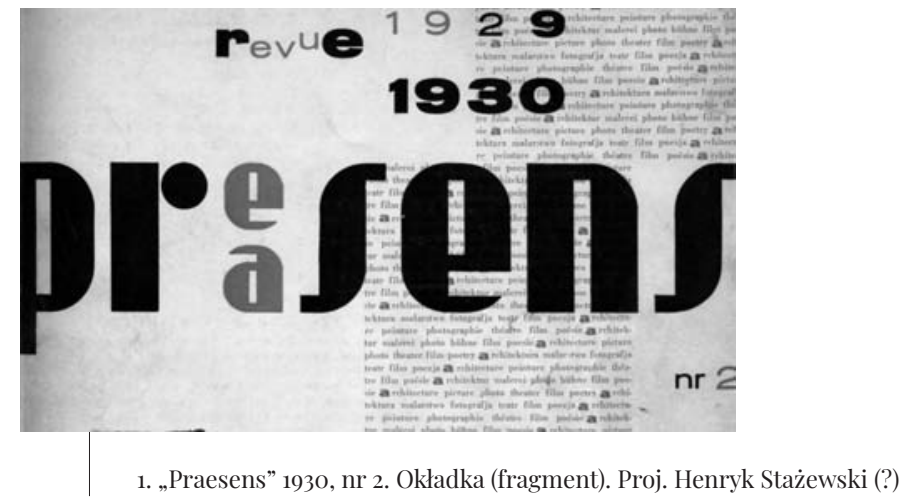

Wartym przywołania, oryginalnym przykładem syntezy sztuk - współgrania architektury, malarstwa i technik teatralnych - był dom współtwórcy Praesensu Bohdana Lacherta przy ulicy Katowickiej $9 \mathrm{w}$ Warszawie. Jego nowoczesna forma została zainspirowana dwiema wersjami seryjnego budynku o nazwie "Citrohan" (pochodzącej od koncernu samochodowego Citroëna finansującego realizacje), zrealizowanymi przez Le Corbusiera i Pierre'a Jeannereta na eksperymentalnej wystawie mieszkaniowej Weissenhofsiedlung w Stuttgarcie ${ }^{7}$. Dom Lacherta to druga - po willi Barbary i Stanisława Brukalskich - awangardowa realizacja na terenie stolicy. To właśnie sceneria tego modernistycznego wnętrza zainspirowała utwór sceniczny o roli koloru w przestrzeni mieszkalnej, a mianowicie Dialog o wnętrzu autorstwa Andrzeja Pronaszki, rozpisany między „Tego” (gościa) i „Owego" (właściciela). Był to przykład integracji dyscyplin sztuk plastycznych i środków wypowiedzi artystycznej o charakterze ekfrazy:

Ów: (...) Petnia światła zawsze dochodzi do mnie niczym nie zatrzymana. Prócz tego ważna niezmiernie rolę odgrywa malowanie wnętrza... 
Ten: Ach, właśnie! Z tym, to się nigdy nie zgodzę! Te ściany, porozbijane kolorowymi płaszczyznami, te prostokaty, kwadraty, a zwłaszcza ten czarny zygzak na suficie! To jest po prostu las przypadkowo rzuconych kolorów, las, w którym można, jak nic, zabładzić!

Ów: Powoli, powoli, kochany przyjacielu! Jeżeli chodzi o błądzenie, to rzecz się ma wprost przeciwnie. Te prostokaty, kwadraty i, jak to pan nazwat? - aha, zygzaki na suficie, nie tylko nie zdezorientuja pana, ale nawet, co prawda bez pańskiej wiedzy, dopomoga pańskiej orientacji. One sugeruja panu kierunek pańskich ruchów, ściśle, poprzednio przez architekta obliczonych.

Ten: Powiedzmy, ale do tego celu wystarczytyby zupetnie strzałki kierunkowe!

Ów: Zapewne, gdyby nie to, że nie byłoby takie załatwienie sprawy ani pięknym, ani celowym. Nie wyobraża pan sobie chyba, żeby dorosły człowiek musiał mieć narysowane w swym mieszkaniu strzałki, aby wiedzieć, w jakim kierunku ma się poruszać!

Ten: Otóż właśnie!

Ów: Chodzi tu raczej, jakby tu powiedzieć, o wywołanie pewnej zgodności. Nic, co by sie panu narzucato, wszystko, co by panu, w pańskich ruchach wtórowato.

Ten: No, dobrze. Powiedzmy, można się zgodzić na te płaszczyzny kierunkowe. Ale po co jest ten system plaszczyzn, i to kolorowych?

Ów: Dla kilku naraz rzeczy. Przede wszystkim do regulacji światła.

Ten: Jak to?

Ów: I to zależnie od celów, do jakich jest przeznaczona dana ubikacja. Ponieważ każdy kolor inaczej odbija światło otrzymywane, jak w tym wypadku z okna (mówimy przecież o wnętrzu), przeto, zależnie od wysokości okna, jego szerokości, jego miejsca w ścianie i przeznaczenia pokoju, komponuje się ściany tak, aby refleksowanie szło po linii pańskich czynności. Gdzieniegdzie tłumi się naświetlenie, gdzieniegdzie sie je wzmacnia.

Ten: Ależ to cała wiedza tajemna. Ciekaw jestem teraz, jakie sa dalsze dobrodziejstwa tego sposobu komponowania przestrzeni!

Ów: Doskonale pan powiedział. Jest to właśnie komponowanie przestrzeni, z wrachowaniem jeszcze jednego czynnika, którym jest ruch. (...)

Każdy kolor ma swoje specjalne cechy. Dobre ich zestawienia ze soba, oparte na podkreślaniu istniejacej architektury, na jej, poniekad, uzupetnianiu, na wydobywaniu jej cech, czyli tłumaczeniu jej, na uzgodnieniu jej idealnie z funkcjami mieszkajacego w niej człowieka, stwarza te atmosfere zgodności, która już w krótkim czasie zaczyna dobroczynnie działać na pańskie samopoczucie. (...)

Skomponowanie wnętrza z kilku barw daje pańskiemu oku odpoczynkowe zajęcie, podczas którego oko pańskie, a za jego pośrednictwem umyst pański bez pracy, bez najmniejszego wysiłku uczy się nowych, dotą nieznanych sobie rzeczy ${ }^{8}$.

Pronaszko, współtwórca (wraz z Szymonem Syrkusem) teatru symultanicznego (1927-1928), członek grupy Praesens, a po odejściu z jej szeregów Henryka Stażewskiego redaktor działu malarstwa w drugim numerze programowego czasopisma, bywał w domu Lacherta, gdzie toczyły się dyskusje awangardowych twórców. Grupę Praesens często charakteryzowano jako grupę dyskusyjną. Jej działalność opierała się bowiem m.in. na cyklicznych spotkaniach, podczas których komentowano aktualne doniesienia ze świata architektury, studiując międzynarodowe czasopisma fachowe i fotografie oraz analizując aktualne zagadnienia projektowe.

\section{Architektura versus film}

Obszar przenikania się architektury i filmu to w badaniach nad modernizmem wciąż terra incognita w porównaniu z refleksją nad migracją fotografii, reprodukcji i narracji wizualnych znaczących dla progresywnego rozwoju architektury nowoczesnej ${ }^{9}$. Przykła- 
dem praktycznej roli wykorzystania zdjęć i grafiki reprodukcyjnej w pracy architektonicznej była zorganizowana przez Praesens między 27 lutego a 25 marca 1926 r. w salach warszawskiej Zachęty I Międzynarodowa Wystawa Architektury Nowoczesnej. Katalog ekspozycji, zestawiony przez architektów Jana Najmana i Lecha Niemojewskiego, wypełnił 11. numer czasopisma „Blok”10, pierwszego awangardowego periodyku firmowanego przez grupę artystyczno-architektoniczną kierowaną przez Mieczysława Szczukę i Teresę Żarnower, z którą początkowo był związany także Syrkus. Na wystawie eksponowano fotografie realizacji modernistycznych (określane jako fotografie z natury) oraz reprodukcje projektów architektonicznych (opisane jako odbitki światłodrukowe). Oryginalne projekty, rysunki, akwarele i makiety pokazali na wystawie wyłącznie architekci z Polski, co wydaje się logiczne w obliczu korespondencyjnej formuły pozyskiwania eksponatów. Francję reprezentowali m.in. Le Corbusier (z pochodzenia Szwajcar) oraz Robert Mallet-Stevens. W przypadku drugiego z nich eksponowano przede wszystkim zdjęcia willi prywatnych oraz koncepcji wystawienniczej zrealizowanej na Międzynarodowej Wystawie Sztuki Dekoracyjnej w Paryżu (1925 r. $)^{11}$. Jednak nie tylko. Pod nazwiskiem Mallet-Stevensa przy numerze VII, w punkcie 17. podano: dekoracja do filmu "Nieludzka” ("L'inhumaine") (fotografia $z$ natury) ${ }^{12}$. Film Nieludzka (L'inhumaine. Histoire féerique) w reżyserii Marcela L'Herbiera, nakręcony w 1924 r., wymykał się jednoznacznym definicjom gatunku. To historia śpiewaczki operowej Claire Lescot, otoczonej amantami i nieczułej nawet wobec śmierci (jak się okazuje - sfingowanej) zakochanego w niej młodego szwedzkiego naukowca, Einara Norsena. Co istotne, akcja filmu rozgrywa się w luksusowych, ultranowoczesnych modernistycznych wnętrzach (dziś obraz ten uznaje się za manifest art déco). Osiągnięty przez L’Herbiera efekt syntezy sztuk był wynikiem współpracy artystów różnych dyscyplin oraz połączenia na planie filmowym architektury, malarstwa, dekoracji wnętrz i muzyki. Scenografię stworzyli Mallet-Stevens we współpracy z Fernandem Légerem, meble zaprojektował architekt Pierre Chareau, a kostiumy - Paul Poiret. L'Herbier, zainspirowany architekturą modernistyczną i sztuką użytkową, wyraził swoją fascynację, eksponując detale wykończenia, różnorodność materiałów i kontrastujące ze sobą faktury przy użyciu eksperymentalnych nocnych ujęć i zmiennego, niekiedy neonowego oświetlenia (sam określił film jako magiczna historię wpisana w nowoczesna sztukę dekoracyjną ${ }^{13}$ ). Opierając się na wizji Légera, zrealizowano w Nieludzkiej wnętrze laboratorium naukowca Norsena, pasjonata mechaniki, automobilisty i sportowca, natomiast według koncepcji Mallet-Stevensa wykonano makiety dwóch barwnych, asymetrycznych nowoczesnych domów - jednego należącego do Lescot, drugiego do Norsena - zlokalizowanych według scenariusza na przedmieściach Paryża. Fotografia scenografii stworzonej przez architekta, eksponowana na wystawie $\mathrm{w}$ Zachęcie, przedstawia zapewne ujęcie elewacji jednej $\mathrm{z}$ willi o geometrycznym podziale, poprzedzonej zadaszonym wejściem z drzwiami wykończonymi różnobarwnymi materiałami (ilustr. 2). Wykonana na potrzeby filmu dekoracja architektoniczna, symbolizująca nowoczesność miasta, stosunkowo szybko znalazła odbicie w obiekcie zrealizowanym - znaczącym, gdyż uznawanym za pionierski awangardowy dom na terenie Warszawy. Chodzi o dom własny Barbary i Stanisława Brukalskich przy ulicy Władysława Niegolewskiego 8 na Żoliborzu (1927-1928) ${ }^{14}$. Okres budowy przypadł na czas aktywnej współpracy architektonicznego małżeństwa z grupą Praesens (jak wspomniano, wkrótce do niej wstąpili). Forma budynku została wprawdzie zainspirowana willą w Utrechcie (1924-1925), zaprojektowaną dla Truus Schröder-Schräder przez Gerrita Rietvelda należącego do holenderskiej grupy De Stijl, jednakże z wyłączeniem drzwi wejściowych. Projekt wejścia z wyraźnym podziałem przecinających się pod kątem prostym listew, $\mathrm{z}$ asymetrycznie wkomponowanymi matowymi i transparentnymi kolorowymi szklanymi 
płycinami, powstał w ramach współpracy Brukalskiego i Bohdana Lacherta ${ }^{15}$. Był refleksem wykończenia utrechckiej willi Rietvelda i echem płócien Pieta Mondriana, ale przede wszystkim zdradzał inspirację scenografią Mallet-Stevensa do filmu Nieludzka (ilustr. 3).

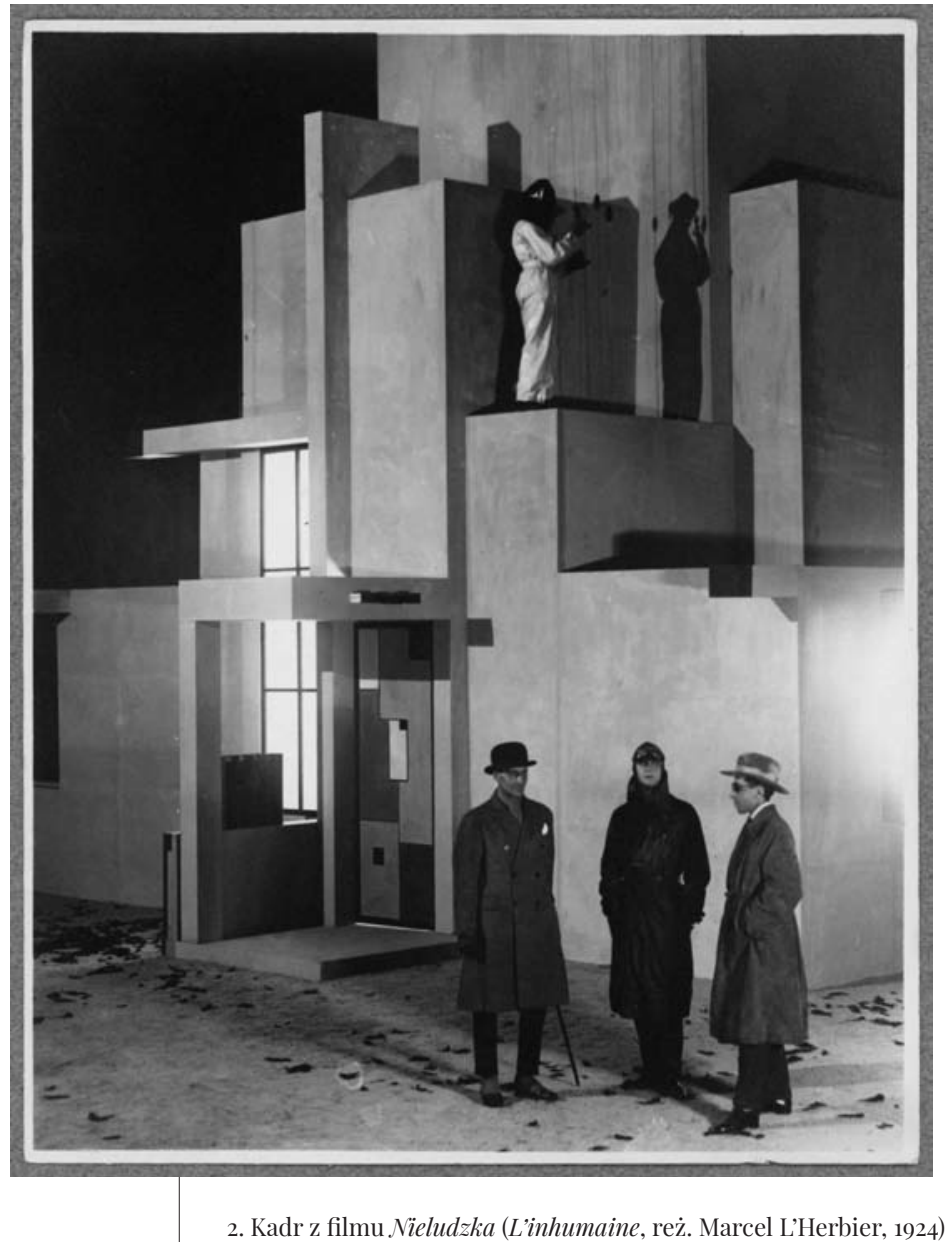

Ponadto w katalogu warszawskiej wystawy pod nazwiskiem tego architekta wymieniono „willę na Rivierze dla hr. N" (nr 14) ${ }^{16}$. Była to asymetryczna, horyzontalna, imponująca rozmiarami biała willa wyposażona $\mathrm{w}$ tarasy i basen, otoczona murem oporowym z charakterystycznymi uskokami, w którym przepruto prostokątne prześwity, uzyskując w ten sposób widok na otaczający krajobraz, tzw. żywe obrazy. Wzniesiona w Hyeres na południowym wschodzie Francji w latach 1923-1927, należała do zamożnych kolekcjonerów sztuki Charles'a i Marie-Laure de Noailles. Oryginalnym elementem tej realizacji, a dziś wręcz jej symbolem, był kubistyczny ogród (określany także jako trójkątny) zaprojektowany przez współpracującego z Mallet-Stevensem Gabriela Guevrekiana. Architekt ten, działający we Francji od 1922 r., był autorem słynnego geometrycznego jardin d'eau et de lumière z trójkątnym podświetlonym basenem oraz lustrzaną kulą pośrodku, zrealizowanego na wspomnianej międzynarodowej paryskiej ekspozycji w 1925 r. (fotografię 


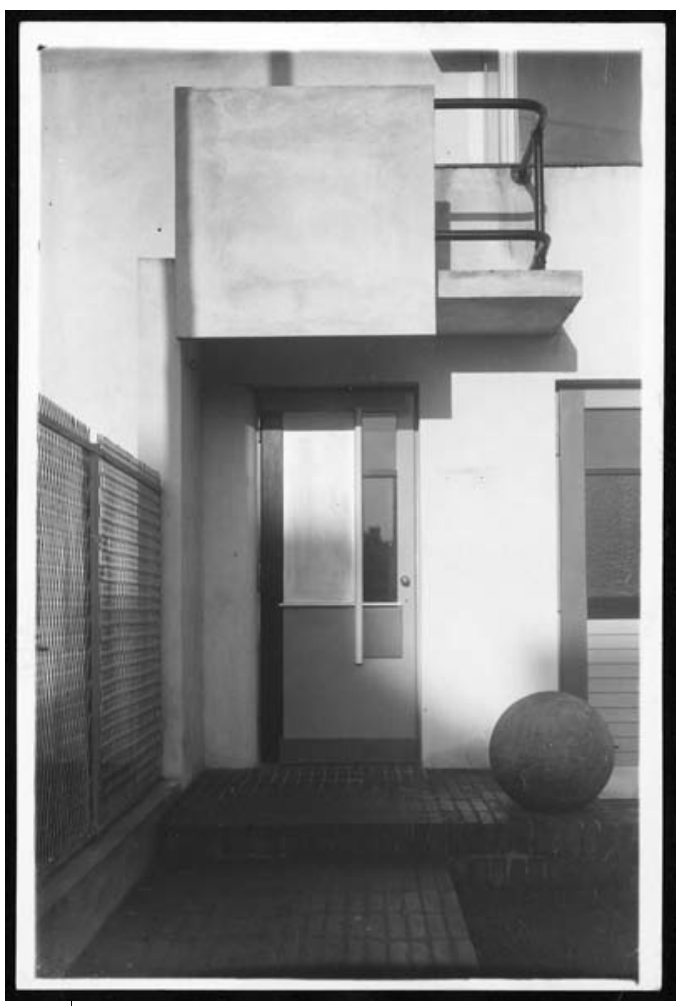

3. Drzwi do domu architektów Barbary i Stanisława Brukalskich. Proj. Stanisław Brukalski, Bohdan Lachert, 1928. Zbiory prywatne

ogrodu także eksponowano w Zachęcie i wymieniono w katalogu jako ogród świetlny na M.[iędzynarodowa] W.[ystawę] S.[ztuki] N.[owoczesnej] w Paryżu 1925) ${ }^{17}$. Dom w Hyeres, pełniący rolę letniej willi, a zarazem centrum artystycznego i galerii sztuki współczesnej, stał się inspiracją dla goszczącego w nim Man Raya. We wnętrzu oraz w otoczeniu tego obiektu umieścił on akcję swojego filmu Les Mystères du Château de Dé (1929), najdłuższego w karierze dadaisty (27 min). Choć fabuła jest tu wyraźnie zarysowana, głównym tematem obrazu pozostaje architektura. Film Man Raya można śmiało porównać do współczesnych spacerów wirtualnych. Dom został sfilmowany z różnych perspektyw, z wykorzystaniem długich najazdów kamery, momentami zatrzymującej się na konkretnych detalach. Grupa aktorów - ubrana w pasiaste trykotaże, o twarzach przysłoniętych maskami, wykonująca zrytmizowane ruchy - wydaje się pełnić role rekwizytów dopełniających modernistyczne przestrzenie (ilustr. 4).

\section{Film architektoniczny/architektura do sfilmowania}

Okres działalności grupy Praesens, a wcześniej formacji Blok, zbiegł się z czasem odkrywania i adaptacji haseł Le Corbusiera przez stołeczne środowisko architektoniczne. Wydana w 1923 r. publikacja W strone architektury (Vers une architecture) ${ }^{18}$ ze względu na formę graficzną była promowana m.in. przez architekta Lecha Niemojewskiego jako oryginalna francuska ksiażka z obrazkami ${ }^{19}$. Wykorzystywała zestawienia zdjęć statków, samolo- 


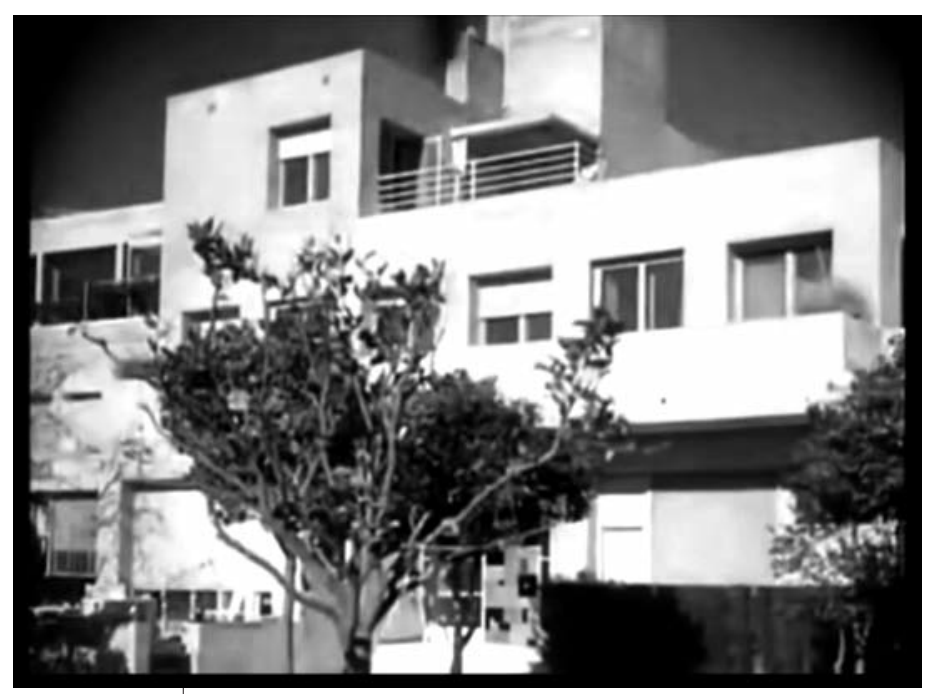

4. Kadr z filmu Tajemnice zamku kości (Les Mystères du Château de Dé, reż. Man Ray, 1928)

tów i elewatorów z greckimi świątyniami, aby zaprezentować przykłady zastosowania prefabrykacji i masowej produkcji, które miały stać u podstaw nowoczesnej architektury. Publikacja ta stanowiła dla Le Corbusiera jeden z etapów procesu poszukiwania zasad czy wręcz algorytmu nowoczesnego domu - „maszyny do mieszkania” budowanej z elementów typowych z koniecznością uwzględnienia dostępu światła, słońca oraz obecności zieleni. Ostatecznie algorytm został sprowadzony do liczby 5 i obejmował: pilotis, czyli słupy, na których wsparto część domu, uzyskując na parterze zadaszoną przestrzeń o dowolnym przeznaczeniu, np. na garaż lub ogródek (1); wolny plan pozwalający na zminimalizowanie liczby ścian nośnych na rzecz lekkich ścianek działowych umożliwiających dowolne kształtowanie przestrzeni wnętrza (2); wolną elewację (3), dzięki wprowadzeniu konstrukcji szkieletowej, która umożliwiała zastosowanie horyzontalnych pasów okien (4) o dowolnych prześwitach, czyli optymalne doświetlenie budynku. Płaski dach mógł zostać zaadaptowany na taras mieszczący ogródek bądź solarium (5). Do tego dochodziły niezbywalne elementy konstrukcji nowoczesnego budynku, czyli „piony”: kanalizacyjny, grzewczy, kuchenny i komunikacyjny. Rozkład pomieszczeń oparto na funkcjonalnym schemacie obejmującym przyziemie gospodarcze, piętro dzienne i sypialną górę. Le Corbusier i Pierre Jeanneret zastosowali ten algorytm w osiedlu robotniczym Quartiers Modernes Frugès w Pessac koło Bordeaux (1924-1926): na parterze szeregowych domów dla robotników umieszczono garaż i pomieszczenie gospodarcze, na pierwszym piętrze kuchnię i pokój dzienny, na drugim sypialnię, na dachu taras ${ }^{20}$. Le Corbusier podjął tu próbę zaprojektowania mieszkań dla zbiorowości przy jednoczesnym zachowaniu indywidualnego charakteru każdego z nich dzięki zastosowaniu elementów typowych w różnych układach ${ }^{21}$. Na marginesie warto zaznaczyć, że liczba 5 miała dla Le Corbusiera szczególne znaczenie. Moduł o długości $5 \mathrm{~m}$ był podstawowy przy opracowywaniu eksperymentalnego osiedla - odcinek o tej długości, określony jako ,jeden zasadniczy wymiar", wyznaczał tam rozstaw słupów, długość podciągów oraz podstawową jednostkę mieszkalną mierzącą $5 \times 5 \mathrm{~m}$, multiplikowaną w celu zwiększenia metrażu lub dzieloną na pół za pomocą lekkiej ścianki²2. Corbusierowski algorytm 5 punktów został zaprezentowany w realnej formie w dwóch modułowych domach na wspomnianej wystawie mieszkaniowej Weissenhofsiedlung 
w Stuttgarcie (1927). Prototypy architektury mieszkaniowej, przeznaczone do dalszych badań, były wynikiem eksperymentów nad integralnością formy i funkcji. Ewoluowały potem w stronę monumentalnych jednostek mieszkaniowych Le Corbusiera (Unité d'habitation) uwzględniających społeczne i usługowe potrzeby mieszkańców (uliczki handlowe na całej długości jednego z pięter), co miało sprzyjać budowaniu społeczności.

Analizując związki architektury Le Corbusiera z filmem, badacze odwoływali się do porównań oryginalnego stylu tekstów i języka architekta z filmem awangardowym ${ }^{23}$. Wizualną narrację o architekcie (w typie picture book) stanowi wydana w 2014 r. monografia Le Corbusier Le Grand autorstwa Jeana-Louisa Cohena, dzięki której można prześledzić drogę twórczości architekta, czytając i oglądając ułożone chronologicznie notatki, zapiski, rysunki, szkice, projekty, artykuły, fotografie ${ }^{24}$. W badaniach stosunkowo rzadko sięga się po filmy architektoniczne bądź urbanistyczne, do których architekci - jak to było w przypadku Le Corbusiera - niekiedy pisali scenariusze. Obrazy prezentowano zazwyczaj na wystawach bądź specjalnie organizowanych pokazach. Za przykład może tu posłużyć Międzynarodowy poranek nowego filmu zorganizowany za poręczeniem grupy "Praesens" $i$ architekta Syrkusa ${ }^{25}$ w kinie Adria 22 stycznia 1933 r. Inicjatorem przedsięwzięcia był - jak wskazał Łukasz Biskupski - Seweryn Mazrycer, inżynier elektryk zajmujący się oświetleniem przestrzeni architektonicznych ${ }^{26}$. Problematyka przeglądu skupiła się na filmach o tematyce architektonicznej - wyświetlono Nowe mieszkanie (Die neue Wohnung, 1930) Hansa Richtera, Philips-Radio (1931) Jorisa Ivensa, Jarmark wielkomiejski (Markt in Berlin, 1929) Wilfrieda Bassego, Architekturę dnia dzisiejszego (Architecture d'aujourd'hui, 1930) Pierre'a Chenala oraz - premierowo - Europę (1932) Franciszki i Stefana Themersonów. Szerszego komentarza w kontekście niniejszego tekstu wymagają dwa z wymienionych filmów. Nowe mieszkanie Richtera to film zamówiony przez Schweizerischer Werkbund (SWB) z okazji wystawy architektonicznej Wohngenossenschaft Basel (WOBA) w Bazylei w $1930 \mathrm{r}$. Zaprezentowano w nim szwajcarski modernizm na tle wybranych realizacji z Europy i Stanów Zjednoczonych, tworząc subiektywną topografię międzynarodowej nowoczesności: w kadrach pojawiło się sanatorium Bella Lui w szwajcarskiej Montanie (Rudolf Steiger, Flora Steiger-Crawford, Arnold Itten, 1928-1930). Architekturę nowoczesną w Niemczech reprezentował dom Henry'ego i Emmy Budge we Frankfurcie nad Menem (Mart Stam, Werner Moser, 1929-1930), choć ani Stam, ani Moser nie byli Niemcami - Stam był Holendrem (ale działał w Szwajcarii), a Werner Moser - Szwajcarem. Sfilmowano także osiedle Weissenhof (autorstwa m.in. Le Corbusiera i Pierre'a Jeannereta, Ludwiga Mies van der Rohe, Marta Stama, Waltera Gropiusa, Jacobusa Johannesa Pietera Ouda, Adolfa Radinga, Hansa Scharouna, Brunona Tauta). Z realizacji Le Corbusiera wybrano Maison Cook w Boulogne-sur-Seine (1926) oraz willę rodziny Savoy w Poissy (1929-1931 ${ }^{27}$. Przy drugim z filmów, Architekturze dnia dzisiejszego, współpracował sam Le Corbusier, który - obok reżysera Pierre’a Chenala - był autorem scenariusza i komentarzy. Muzykę skomponował kuzyn architekta, Alfred Jeanneret. Film ten, którego premiera odbyła się w maju 1931 r. w paryskim kinie Rialto, należał do trylogii filmów architektonicznych Chenala, jednak w Warszawie pokazano tylko ten segment (drugi to Bâtir /1930/, trzeci - Trois chantiers /1931/). Pod względem scenariuszowym film przypominał reportaż dokumentujący twórczość współautora. W scenach początkowych przedstawiono przegląd różnorodnych sposobów zastosowania betonu i żelbetu. Z budynków sakralnych wybrano realizacje braci Augusta i Gustawa Perret, jako przykład domów mieszkalnych sfilmowano uliczkę zaprojektowaną w całości przez Roberta Mallet-Stevensa (obecnie rue Mallet-Stevens w Paryżu) oraz osiedle Frugès w Pessac Le Corbusiera. Wybór Perretów i Mallet-Stevensa wiązał się zapewne z tym, że to oni zainwestowali kapitał w omawiany 
film. W kolejnych sekwencjach zaprezentowano realizacje Le Corbusiera: willę Stein in Garches (1925-1926) - na ekranie pojawił się sam projektant wspinający się na dach-taras, willę Church w Ville d'Avray (1927) oraz willę Savoye w Poissy (1928-1930; ilustr. 5). Ujęcia wnętrz opatrzono komentarzem: bez sztucznego światła, podkreślając w ten sposób zasadność zastosowania horyzontalnych pasów okien wprowadzających optymalną ilość naturalnego światła. Dodatkowo - w formie zainscenizowanego ujęcia - zaprezentowano zalety tarasu służącego jako solarium bądź przestrzeń przeznaczona do gimnastyki na świeżym powietrzu. Architekturę dnia dzisiejszego wieńczy rewolucyjna wizja nowego centrum Paryża - Corbusierowski plan Voisin (1925) zakładający wyburzenie historycznej zabudowy miasta i wystawienie na planie krzyża modułowych drapaczy chmur w otoczeniu ogrodów, boisk, kortów do tenisa oraz sieci bezkolizyjnych dróg z wielopoziomowymi skrzyżowaniami. Koncepcja radykalnej modernizacji Paryża została sfinansowana przez awiatora i projektanta samochodów Gabriela Voisina. Paryż miał ponownie - jak po rewolucyjnej przebudowie miasta z inicjatywy prefekta barona Georges'a Hausmanna w latach 1852-1870 - stać się europejskim miastem o szczególnym statusie. Chenal sfilmował makiety niebotyków oraz model całego kwartału nowej stolicy Francji, a ich ujęcia zestawiono w montażu z ciemnymi, krętymi uliczkami Paryża ${ }^{28}$. W filmie pojawił się ponadto znany kadr z dłonią Le Corbusiera wskazującą utrwaloną w formie makiet i modeli wizję, powszechnie uznawany za odrębną fotografię i rzadko kojarzony w obrazem Chenala.

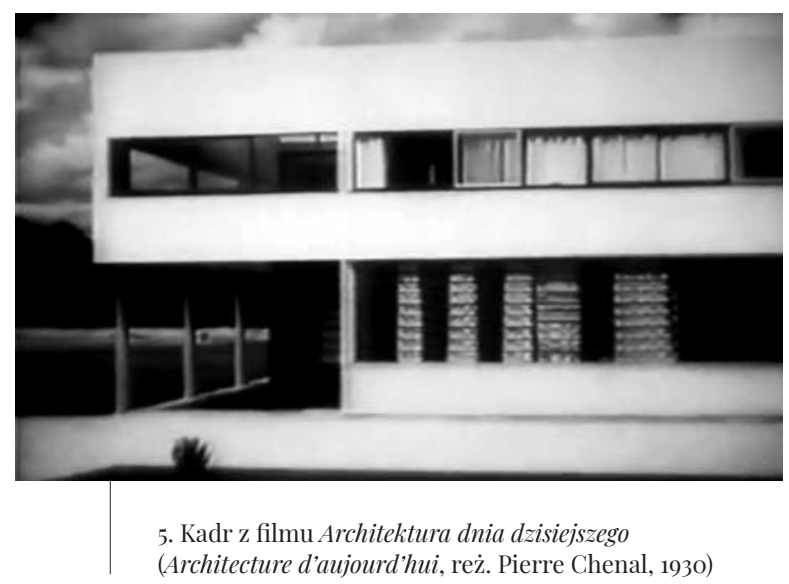

Do grupy filmów, w których architektura modernistyczna odegrała rolę pierwszoplanową, należał także Czarny kot (The Black Cat, 1934) w reżyserii Edgara G. Ulmera, stanowiący swobodną interpretację opowiadania Edgara Allana Poe. Ta produkcja klasy B powstała w hollywoodzkim Universal Studio, z udziałem Borisa Karloffa (aktora znanego $\mathrm{z}$ wcielenia monstrum doktora Frankensteina) i Beli Lugosiego (zwykle grającego postacie wampirów). Film opowiada o młodym małżeństwie, które podróżując pociąiem po Węgrzech poznaje nieznajomego i korzystając z jego zaproszenia, trafia do tajemniczego zamku. Wnętrza budowli okazują się na wskroś awangardowe, a gospodarz, Hjalmar Poelzig, charyzmatycznym architektem wizjonerem, a przy okazji wyznawcą szatana. Dla historyków architektury nazwisko Poelzig wywołuje konkretne skojarzenia. Jest to bowiem nazwisko znanego architekta niemieckiego (1869-1936), Hansa Poelziga, współtwórcy stowarzyszenia Der Ring promującego nowoczesność, wizjonera lokującego własną twórczość między tradycyjnym modelem kształtowania przestrzeni a eksperymentalną awangardą. Do spekta- 
kularnych projektów Poelziga należał berliński Große Schauspielhaus stworzony dla Maxa Reinhardta w 1919 r. oraz scenografia do filmu Golem (Der Golem wie er in die Welt kam, reż. Paul Wegener, Carl Boese, 1920), przy której współpracował właśnie Ulmer. Główny bohater filmu, architekt Hjalmar Poelzig, otrzymał więc identyczne inicjały jak wciąż przecież żyjący niemiecki projektant. Czarny kot stanowił połączenie powieści gotyckiej, filmu grozy, niemieckiego ekspresjonizmu, symbolizmu oraz fascynacji architekturą modernistyczną (autorem dekoracji był Charles D. Hall). We wnętrzu zamku można zobaczyć spiralne schody, chromoniklowane klamki, okrągłe lustra, okna w formie bulajów, ściany z luksferów i elektryczne oświetlenie (ilustr. 6). Ulmer, z wykształcenia architekt wnętrz, ukazał modernistyczne wystroje niezwykle detalicznie, stosując długie zbliżenia na elementy wyposażenia. Czysta, purystyczna przestrzeń i kojarząca się z zimnem chromowana stal potęgowały brutalizm scen i bezsilność głównych bohaterów złapanych w pułapkę. W przypadku Ulmera fascynacja nowoczesną architekturą nie była czymś nowym - rozpoczynał karierę u boku Friedricha Wilhelma Murnaua i przypisywał sobie również współautorstwo „reżyserii obrazu” i „scenografii filmowej” Metropolis (1927) Fritza Langa. Kilka lat przed nakręceniem Czarnego kota sięgnął po temat urbanistyczny - tytuł filmu, który zrealizował, Ludzie w niedziele (Menschen am Sonntag, 1930), miał pierwotnie brzmieć po prostu Berlin. Pozbawiony wyraźnej dramaturgii obraz stanowił impresję na temat jednego dnia z życia metropolii.

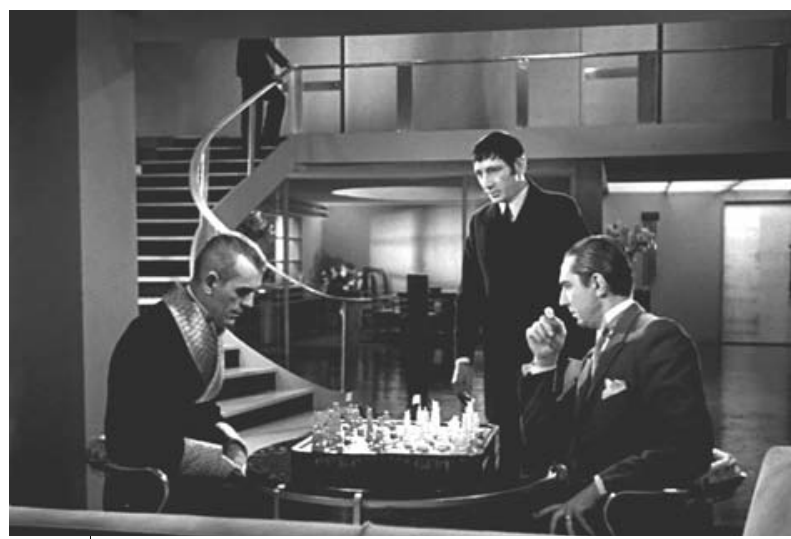

6. Kadr z filmu Czarny kot (The Black Cat, reż. Edgar G. Ulmer, 1934)

\section{Narracje symultaniczne}

Połączenie wizji nowoczesnej architektury i wizerunku jej projektantów, jak w przypadku kadru z Le Corbusierem wskazującym na plan Voisin dla Paryża, uobecnia się też na popularnych w środowiskach międzynarodowej awangardy zdjęciach twórców z modelami budynków. W konteście holenderskiej grupy De Stijl można tu przywołać znaną fotografię Theo van Doesburga i Cornelisa van Eesterena z modelem awangardowego domu maison d'artiste (domu artysty) czy też samego van Doesburga pracującego nad modelem maison particulière (domu prywatnego) - obie zostały wykonane w pracowni artysty przy Rue du Moulin Vert w Paryżu w 1923 r. Do grupy ujęć z serii „twórca i dzieło” zaliczał się reprodukowany w "Praesensie” fotomontaż przedstawiający dom własny Bohdana Lacherta, ukazany w trakcie budowy, z wkomponowanymi rzutami poszczególnych 
kondygnacji oraz podwójnym portretem Lacherta i Szanajcy. Fotomontaż ten był nie tyle wizualizacją obiektu, ile ideogramem nowoczesnego domu. Prezentował rzuty poziome kondygnacji, usytuowanie budynku względem stron świata oraz szczegóły techniczne konstrukcji szkieletowej ${ }^{29}$. Szkielet wypełniono celolitowymi taflami z felcowaniem do szybkiego i nieskomplikowanego montażu w prowadnicach żelaznych żeber. Fotomontaż ilustrował 5 zasad architektury Le Corbusiera: konstrukcję na słupach (pilotis), wolny plan, wolną elewację, pasmowe okna i taras. Składową architektonicznego ideogramu była także zastosowana technika opracowania wizualizacji domu architekta. Termin określający wykorzystaną technikę, zawierający słowo ",montaż”, mógł być kojarzony z technologią wykonania domu standaryzowanego (seryjnego), opartą na montażu elementów prefabrykowanych. Symultaniczna narracja, skomponowana z wybranych kadrów, pod względem formalnym była jednocześnie bliska awangardowym filmom eksperymentalnym, opartym na montażu pojedynczych, nieruchomych kadrów.

W 1933 r. Bohdan Lachert we współpracy z Janem Najmanem i Zbigniewem Pugetem opracowali monumentalny fotomontaż Polonia o wymiarach $6 \times 3 \mathrm{~m}$. Był on prezentowany na V Triennale di Milano. L'Esposizione Internazionale delle Arti Decorative e Industriali Moderne e dell'Architettura Moderna. Koncepcja mająca promować Polskę została opracowana wyłącznie przez architektów, którzy sięgając po fotografie obiektów modernistycznych z terenu Warszawy, stworzyli wizję nowoczesnego państwa ${ }^{30}$. Program ekspozycyjny został opracowany przez przewodniczącego komisji wystawowej, Stanisława Brukalskiego, zaś ze strony włoskiej w organizację wydarzenia był zaangażowany architekt Gio Ponti. Zestawienie tych dwóch nazwisk nie jest przypadkowe - Brukalski przed rozpoczęciem edukacji na Wydziale Architektury Politechniki Warszawskiej studiował na Politechnice w Mediolanie, którą w 1921 r. ukończył Ponti ${ }^{31}$. Propagandowy fotomontaż Polonia stanowił wystawienniczy „program minimalny"32, a opracowano go w konwencji kompozycji Metropolis berlińskiego dadaisty Paula Citroena z 1923 r., znanej zapewne jego twórcom (motyw miasta pojawiał się na okładkach wydawnictw książkowych od połowy lat 20. zarówno w Polsce, jak i Europie) $)^{33}$. Wielkomiejski fotomontaż Citroena miał niewielkie wymiary $(20,3 \times 15,3 \mathrm{~cm})$, podczas gdy Polonia była planszą monumentalną. Różnica pomiędzy kompozycjami polegała także na tym, że w Polonii wyeksponowano gmachy o różnych funkcjach i przeznaczeniu, podczas gdy Metropolis było efektownym zestawieniem kilku modułowych ujęć drapaczy chmur, kilkakrotnie dublowanych. Nawiązanie do Metropolis mogło być jednym z kodów programujących odbiór II Rzeczypospolitej jako państwa nowoczesnego. Przyjętą konwencję ekspozycyjną można także połączyć z nowatorskim charakterem samego triennale. Wizja berlińczyka miała wówczas szerokie oddziaływanie: można z dużym prawdopodobieństwem przyjąć, że wpłynęła na ultranowoczesny kształt miasta przyszłości w filmie o identycznym tytule, a mianowicie Metropolis Fritza Langa - reżysera, który wcześniej studiował architekturę w wiedeńskiej Wyższej Szkole Technicznej, zaś później malarstwo w Wiedniu i Monachium. Być może to przypadkowa zbieżność, ale jednym z bohaterów filmu Langa był robot (czy też Maschinenmensch) Futura - tak brzmiała też nazwa bezszeryfowego kroju pisma zaprojektowanego w latach 1924-1926 przez Paula Rennera, profesora Bauhausu ${ }^{34}$. To zarazem jedno ze słów-kluczy nowoczesności (w 1931 r. odlano czcionki futury w Polsce, nadając krojowi nazwę Paneuropa i to właśnie ten krój wykorzystano w fotomontażu Polonia).

Rok po mediolańskiej ekspozycji architekci Szymon Syrkus i Jan Chmielewski ukończyli studium Warszawa funkcjonalna. Przyczynek do urbanizacji regionu warszawskiego (1934). Ta oryginalna koncepcja urbanistyczno-architektoniczna była promowana nie tylko za pośrednictwem tekstu, ale także dzięki umiejętnie rozwiązanym planszom z diagramami au- 
torstwa Jerzego Hryniewieckiego ${ }^{35}$. Syrkus prezentował założenia miasta funkcjonalnego w 1933 r. na IV Congrès International d'Architecture Moderne. Kongres odbywał się na statku Patris II płynącym z Marsylii do Grecji (pierwotnie miał być zorganizowany w Moskwie, ale ze względów zaostrzającej się polityki kulturalnej nie doszło to do skutku) ${ }^{36}$. Podczas obrad opracowano postulaty nowoczesnej urbanistyki, które - wzbogacone komentarzami opublikował później Le Corbusier pod nazwą Karta ateńska ${ }^{37}$. Okoliczności powstawania tego manifestu możemy prześledzić, sięgając po filmowy dziennik (w czołówce określony jako film tagebuch-diary-journal) Lászla Moholy-Nagya ${ }^{38}$ - malarza, fotografa, autora filmów eksperymentalnych, profesora Bauhausu. Następujące po sobie migawki z mijanych miast przeplatają się z dokumentacją pracy kongresu - zapisem odczytów, dyskusji, kuluarowych rozmów, pisania notatek na maszynie, życia towarzyskiego, funkcjonowania statku (ilustr. 7). Ujęcia z postoju w Atenach układają się w krótki film o greckim modernizmie i realizacjach Stamo Papadakiego, także uczestniczącego w pracach kongresu. Obraz Moholy-Nagya stanowi fenomenalne źródło badań nad architekturą nowoczesną jako dokument o charakterze artystycznym oraz dziennik filmowy obfitujący w zbliżenia architektek, architektów i plastyków, takich jak Alvar Aalto, Cornelis van Ees teren, Charlotte Perriand, Ferdinand Léger, Le Corbusier oraz Helena i Szymon Syrkusowie, Barbara i Stanisław Brukalscy, Anatolia Hryniewiecka-Piotrowska i Roman Piotrowski.

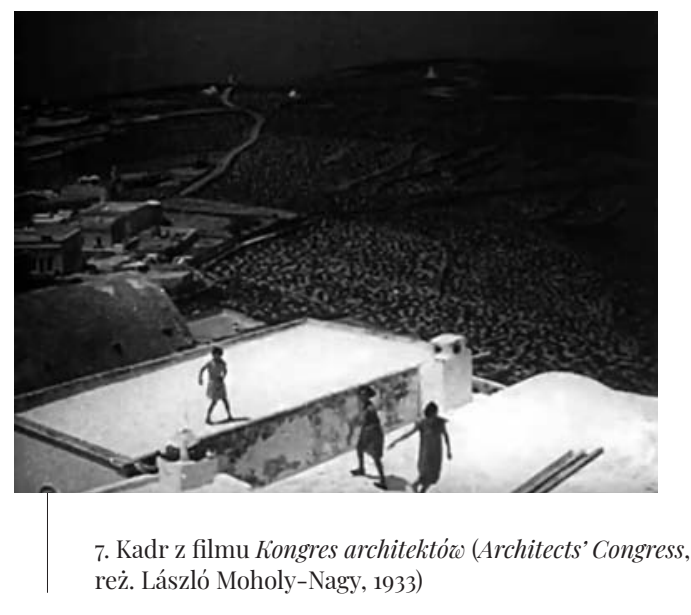

\section{Eksperymentalny WSM}

W 1930 r. Praesens połączył siły z Warszawską Spółdzielnią Mieszkaniową na Żoliborzu - zmienił wówczas nazwę (zaczął się określać jako zespół, a nie grupa modernistów) oraz strukturę, pozostawiając w swoich szeregach jedynie architektów, konstruktorów i inżynierów, czyli przedstawicieli profesji, którzy praktycznie mogli zaangażować się w budowę nowych osiedli. Ogłoszone wówczas hasło programowe brzmiało: nadrzędnym celem jest architektura społeczna, a modus operandi ma stanowić praca kolektywna. Fenomen żoliborskiej WSM, założonej przez Stanisława Tołwińskiego i Teodora Toeplitza (stryja Jerzego Toeplitza) oraz wzorowanej na amerykańskiej koncepcji jednostki sąsiedzkiej (neighborhood unit) Clarence'a Perry'ego, polegał nie tylko na przyjaznej człowiekowi skali budynków zgrupowanych w kolonie liczące 300-400 niewielkich, funkcjonalnie zaprojektowanych mieszkań. Osiedle żoliborskie wyróżniało się przede wszystkim opracowaniem architektury wspólnoty, czyli „przestrzeni społecznych” - kompleksu obiektów do wspól- 
nego użytkowania, takich jak pralnia, łaźnia, sale zebrań, lokale klubowe, biblioteki, czytelnie, świetlice dla dzieci i młodzieży z tzw. salami ciszy, poradnie specjalistyczne oraz teatry: „Baj” dla dzieci oraz teatr dla dorosłych. W celu organizacji tego ostatniego zmodernizowano pomieszczenia osiedlowej kotłowni (ul. Suzina 4, obecnie 6-8), wzniesionej według projektu Brunona Zborowskiego i inżyniera Ludwika Merkela (1928-1929). Budynek wyróżniał się w panoramie bloków smukłym kominem oplecionym spiralnymi schodami. Zapewne w 1932 r. rozpoczęto adaptację pomieszczeń kotłowni na kinoteatr z salą „teatralno-koncertowo-odczytową" według koncepcji Szymona Syrkusa. Rok później z inicjatywy Ireny Solskiej działało tu krótko eksperymentalne Studio Teatralne im. Stefana Żeromskiego. Inauguracyjnym przedstawieniem był Boston. Reportaż sceniczny w 48 obrazach B. Blume'a na podstawie dramatu Bernharda Blume'a W imieniu ludu, wyreżyserowany przez Michała Weicherta (wystąpił pod pseudonimem Michał Brandt). Spektakl przywoływał toczący się w Bostonie w latach 1920-1927 proces dwóch włoskich robotników, Nicoli Sacco i Bartolomea Vanzettiego, skazanych przez ławę przysięgłych na karę śmierci pomimo silnych protestów środowisk o lewicowych przekonaniach. Reportaż sceniczny, zagrany po raz pierwszy w języku jidisz w Żydowskim Studiu Eksperymentalnym Teatr Młodych $w 44$ scenach $^{39}$, został wystawiony po polsku 31 maja $1933 \mathrm{r}$. w rozszerzonej wersji, w „ukształtowaniu przestrzennym” Szymona i Heleny Syrkusów (na plakacie widniał pseudonim artystów - Urban Bach). Za określeniem „ukształtowanie przestrzenne” krył się w istocie teatr symultaniczny - artystyczna odpowiedź na faktomontaż. Akcja reportażu scenicznego toczyła się bowiem w 15 miejscach i architekci, we współpracy z reżyserem, zdecydowali się na kilka nowatorskich rozwiązań: zniesienie sceny i kurtyny, odgrywanie scen równocześnie w różnych miejscach sali (jednoczesność czasu i przestrzeni), zniesienie granicy przestrzeni dla widzów i aktorów (rzędy dla widzów zaadaptowano na ławę przysięgłych), sprowadzenie rekwizytów do symbolu (krzesło i stolik służyły jako gabinet, a jako okno - przeszklona ściana z doniczką) ${ }^{40}$. Koncepcja Syrkusów opierała się na elementach ruchomych (mobilne podesty i system zapadni), wykorzystaniu przedmiotów użytkowych oraz ściśle określonej reżyserii ruchu aktora i uwagi widza, którego wzrok, sprowokowany punktowym oświetleniem, był kierowany w konkretne miejsce sceny. Scenografia objęła struktury przestrzenne i ramowe konstrukcje o niedopowiedzianym przeznaczeniu (pod względem formy przypominały system rusztowań), tworząc w ten sposób wizję tytułowego amerykańskiego miasta z ulicznymi szyldami oraz hotelem Carlton. Scenografię wykreowaną przez Syrkusów udokumentowano na kilku fotografiach i rzutach rozplanowania sali wraz z planem reżyserii ruchu aktorów ${ }^{41}$ (ilustr. 8). O efekcie, jaki udało się osiągnać, świadczyła hipotetyczna rozmowa entuzjasty sztuki Boston (Jana) z interlokutorem o odmiennym poglądzie (Zygmuntem) zamieszczona na łamach „Tygodnika Ilustrowanego":

Zygmunt: Włosi? Ależ byli oni najzwyklejszymi pionkami. Rozumiesz: jeśli ma być reportaż - niechaj mi daje petne światła. Niechaj oświetla motywy czynów.

Jan: Za dużo wymagasz od tej formy widowiska. Chciałbyś mieć studium człowieka i sprawy; ujrzeć tajne korytarze, w których jednostka bezsilnie błąka się i rozbija... A w "Bostonie" daja ci pośpiesznie kręcony film, zaprawiony tendencja przeciwko sądom amerykańskim. Całość jest żywa i nie nudna $a^{42}$.

Przedstawienie Boston oglądała mieszkająca na osiedlu WSM reżyserka Wanda Jakubowska, której wojenne losy splotły się wkrótce z życiorysem Syrkusa. 30 października 1942 r. architekta aresztowano i wywieziono do obozu koncentracyjnego Auschwitz-Birkenau (numer obozowy 17165). Przebywał w nim do zimy 1945 r., po czym był przenoszony do obozów przejściowych (Leoberg, Kaufering, Landsberg, Mühldorf) w Bawarii ${ }^{43}$. Jakubowska trafiła do Auschwitz-Birkenau 28 kwietnia 1943 r. (numer 43513), gdzie po zgło- 


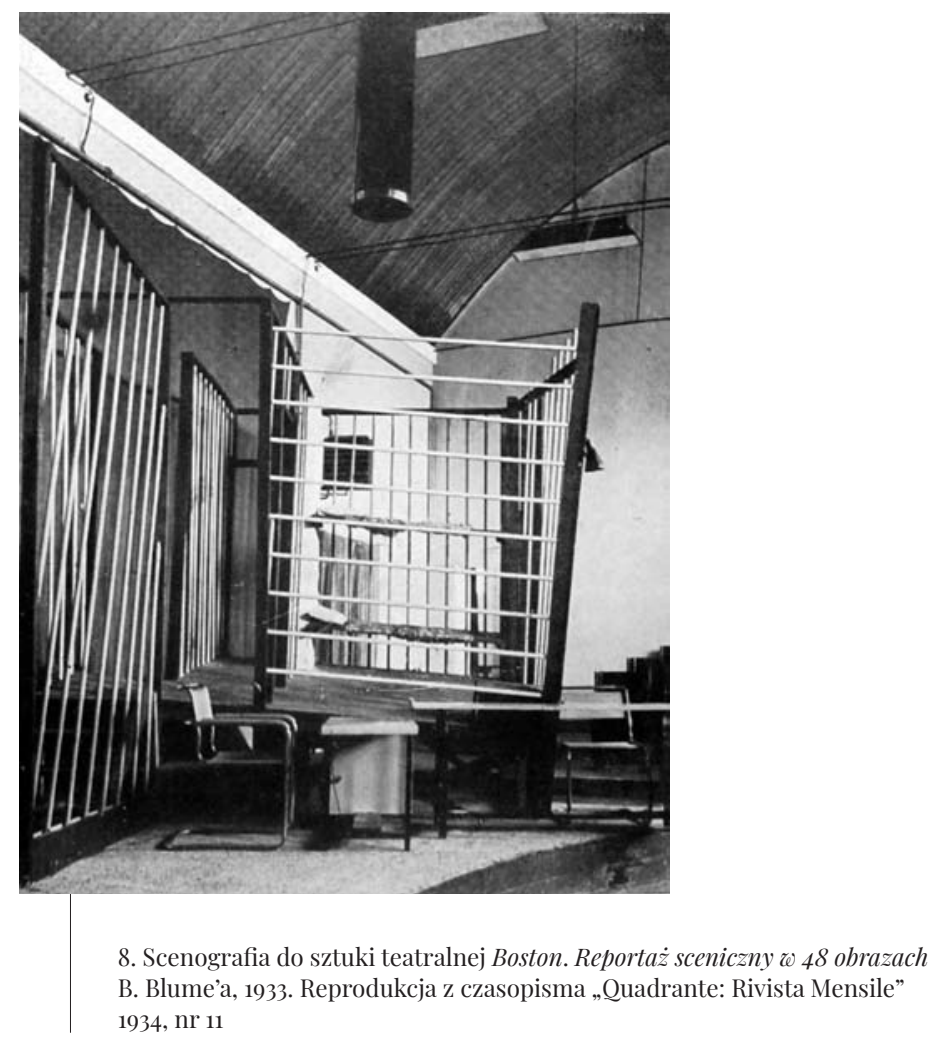

szeniu chęci pracy w charakterze fotografki została przydzielona do obozu kobiecego (pobocznego) w Rajsku. Funkcjonowało tu obsługiwane przez więźniarki gospodarstwo rolne oraz doświadczalne uprawy azjatyckiego koksagizu, z którego pozyskiwano kauczuk. Jakubowska wykonywała dokumentację rysunkowo-fotograficzną roślin. Jednocześnie angażowała się w lewicowy ruch oporu, pełniła funkcję łączniczki z obozem centralnym i gromadziła dokumentację do planowanego w przyszłości filmu. Scenariusz pod tytułem Oświęcim powstawał od czerwca do października 1945 r. Na przełomie lat 1945 i 1946 Jakubowska zabiegała u Aleksandra Forda, dyrektora Filmu Polskiego o przydzielenie jej tematu losu kobiet w obozie Birkenau, wskazując Szymona Syrkusa jako ewentualnego autora dekoracji scenicznych ${ }^{44}$. Film Ostatni etap powstał w 1947 r. (premiera w roku 1948). Scenografię wykonali ostatecznie Roman Mann i Czesław Pstrokoński - Syrkus był już wówczas zaangażowany w działania na rzecz Biura Odbudowy Stolicy. Na początku 1946 r. z ramienia BOS podróżował do Wielkiej Brytanii i Stanów Zjednoczonych, prezentując wystawę Warsaw lives again (oryginalny polski tytuł Warszawa oskarża) ${ }^{45}$.

\section{Symultanizm (podsumowanie)}

Szymon Syrkus, komentując popularne w dwudziestoleciu międzywojennym pojęcie symultanizmu (wykorzystane jako motto w koncepcji zaprojektowanego przez niego we współpracy z Pronaszką teatru symultanicznego), posłużył się językiem łudząco przypominającym szkic scenariusza filmowego, którego tematem wiodącym mogło być nowoczesne miasto. Jednocześnie podjął próbę odpowiedzi na pytanie, jaką rolę pełni w odniesieniu do tego zjawiska projektant: Statem któregoś dnia przy Bahnhof am Zoo 
w Berlinie, wciagnięty, ogarnięty tempem życia wielkiego miasta. Koło mnie śmigały auta, autobusy $i$ tramwaje. Ponad moja głowa przesuwały się pociagi dalekobieżne i miejska kolej napowietrzna. Gdzieś wyżej jeszcze aeroplany. A pod nogami, w tunelach, huczała kolej podziemna. W tej różnokierunkowej sieci mechanicznych pojazdów przesuwały się nieprzerwanie fale publiczności. Co chwila otwory, łaczace rozmaite poziomy stacji, wyrzucały nowe tłumy ludzi, nowe fale powietrza, o innej już temperaturze.

W owej chwili wyobraziłem sobie przekrój nowoczesnego miasta z jego różnorodnemi płaszczyznami różnokierunkowych ruchów, ze wszystkiemi kanałami, taczacemi pionowo stacje tych wszystkich kolei. I zrozumiatem, że ów SYMULTANIZM - jednoczesność różnogatunkowych zjawisk, jest znakiem czasu, w którym żyjemy. Człowiek, który raz odnalazł symultanizm gdzieś w sercu wielkiego miasta, nie umie już po prostu myśleć inaczej i dlatego wszędzie szuka symultanizmu.

Film symultaniczny, fotografja symultaniczna fascynuja reżyserów i operatorów. (...)

A architekt?

Architekt nie tylko widzi i czuje symultanizm jak każdy człowiek żyjacy w wielkiem mieście, nie tylko pokazuje go, jak inscenizator filmowy, czy teatralny, ale projektujac miasta i domy, myśli nie tylko przestrzennie, ale symultanicznie - to znaczy ma przed oczami przekroje ruchów, jakie się w obrębie projektowanej przez niego architektury odbywać będa. I reżyseruje tak, ażeby symultanizm ten nie przerodził się w chaos; ażeby kompozycji ruchów nadać walory nie tylko funkcjonalne, ale plas tyczn $e^{46}$.

Z wypowiedzi architekta można łatwo odczytać, że wybrany przez siebie zawód definiował niezwykle szeroko. Trzeba podkreślić, że to właśnie wtedy rodziły się nowe standardy profesji, co zdawała się legitymizować nazwa Praesens (powyższy fragment pochodzi z Tempa architektury, jednego z manifestów grupy). W czasie, kiedy Le Corbusier po długim procesie poszukiwań niejako zamknął całą architekturę w kilku zasadach, Syrkus analizował procesy i ruchy człowieka w przestrzeni. Efektem tych działań miało być projektowanie architektury w harmonii z człowiekiem oraz tworzenie ludzkich mikroświatów. Tak rozumiana architektura miała wiele wspólnego nie tyle z samym filmem jako gotowym efektem, ile z pracą reżysera. Architekt miał nie tylko projektować budynki, ale też, za pomocą artystycznych środków wyrazu, opracować strategie ich użytkowania. Na pokrewieństwo między architekturą i filmem wskazują też pojęcia odsyłające do kinematografii: „reżyseria ruchów w obrębie projektowanej architektury” czy „reżyseria ruchów w przestrzeni". Komentowany już pogląd Canuda o filmie jednoczącym wszelkie inne dyscypliny, i postawiona z nim na szali opinia Syrkusa o architekturze jako dyscyplinie, której mają podlegać wszystkie pozostałe, równoważą się w momencie, gdy modernizm definiujemy jako sposób rozumienia świata, postawę twórczą aktywnie komentującą współczesność, a projektowanie jako interdyscyplinarny dialog. Wówczas te dwa odmienne poglądy możemy uznać za dwugłos - figurę kluczową dla rozumienia i interpretacji zjawisk kultury artystycznej modernizmu. Wydaje się, że harmonia rysuje się także tam, gdzie separowanym od siebie dyscyplinom brakuje narzędzi. Wizualny język architektów w dwudziestoleciu międzywojennym był niezwykle bogaty i oryginalny, jednakże przewidywany ruch człowieka w przestrzeni architektonicznej był oznaczany w sposób tradycyjny na dwuwymiarowych projektach - z wykorzystaniem strzałek wskazujących kierunki poruszania oraz komentarzy objaśniających symbole graficzne. Z pomocą przyszedł film dysponujący możliwością zapisu ruchu. Na polu łączenia architektury i ruchomego obrazu przewagę wśród architektów znów zyskał Le Corbusier dzięki filmowi Architektura dnia codziennego Chenala, w którym on sam (bądź inne sfilmowane osoby) poruszał się zgodnie $\mathrm{z}$ wyreżyserowanym przez architekta ruchem w przestrzeni willi Savoy w Poissy. Film pełnił tu rolę przewodnika. W odniesieniu do pol- 
skiej awangardy tę filmową „,instrukcję obsługi” architektury mogą równoważyć jedynie oryginalne fotomontaże. Proporcjonalnie język filmu stawał się także znacznie bogatszy, kiedy rejestrowano na taśmie wizje architektów. W odniesieniu do samych badań nad architekturą i filmem łączenie tych dwóch dyscyplin stanowi rzadkość. Grupa modernistów Praesens stała się więc punktem wyjścia, a zarazem oferowała rodzaj soczewki, w której skupiła się działalność architektoniczno-filmowa awangardy omówiona w niniejszym tekście.

${ }^{1}$ Wilhelm Thiele (1890-1975) - austriacki reżyser i autor scenariuszy; Victor Janson (1884-1960) - niemiecki aktor oraz reżyser pochodzenia łotewskiego.

2 Zob. film dokumentalny Stanisława Janickiego Scenograf rekordzista - Jacek Rotmil, 2013. Postać Rotmila została także przypomniana na wystawie Mieszkańców portret włas$n y$, towarzyszaccej 3. edycji SDFO (Szare Domy Festiwal Otwarty) w 2018 r. Kuratorki: Marta Surowiec, Katarzyna Uchowicz. Jacek Rotmil mieszkał na osiedlu Szare Domy w Warszawie. Zginął podczas masowych egzekucji w warszawskim getcie.

${ }^{3}$ J. Piłatowicz, Syrkus Helena z Eliasbergów, w: Polski Słownik Biograficzny, t. 46, Warszawa - Kraków 2009-2010, s. 288; J. Minorski, Polska nowatorska myśl architektoniczna w latach 1918-1939, Wydawnictwo Naukowe PWN, Warszawa 1970, s. 27.

4 [spis członków Grupy Modernistów Praesens], „Praesens” 1926, nr 1 (czerwiec), strona tytułowa verso.

5 „Praesens” 1926, nr 1 (czerwiec), s. 64. Zachowano oryginalną pisownię.

${ }^{6}$ Szymon Syrkus (1893-1964) rozpoczął edukację architektoniczną w 1912 r. w Grazu i Wiedniu, w 1914 r. trafił na Politechnikę Ryska, z której przeniesiono architekturę na uczelnie w Moskwie i Dorpacie. Studiował tu do 1917 r., w którym powrócił do Polski. W 1920 r. uzyskał dyplom Szkoły Sztuk Pięknych w Krakowie, w 1922 r. warszawskiego Wydziału Architektury Politechniki Warszawskiej. Archiwum SARP, karta ewidencyjna architekta Szymona Syrkusa, dat. 10.10.1954.

${ }^{7}$ J. N. J. [J. N. Jankowska], Osiedle eksperymentalne na wystawie mieszkaniowej w Stuttgarcie, "Architektura i Budownictwo" 1927, nr 11-12, s. 339-346.

${ }^{8}$ A. Pronaszko, Dialog o wnętrzu, „Dom. Osiedle. Mieszkanie" 1929, nr 10-11-12, s. 4-7.

${ }_{9}^{9}$ Zob. A. Rejniak-Majewska, Obraz zwielokrotniony. Reprodukcja fotograficzna i wizualne narracje sztuki awangardowej 1910-1939, Wydawnictwo Uniwersytetu Łódzkiego, Łódź 2017. Analiza ta objęła m.in. przenikanie się dyscyplin służących dokumentacji i reprodukowaniu obiektów, poszerzanie ich granic (odmiany fotografii i grafiki reprodukcyjnej, fotografia jako sztuczna pamięć historii sztuki) oraz przybliżenie sposobów funkcjonowania międzynarodowej sieci wydawniczej awangardy, w której uwzględniono dokonania grupy Blok zapewne ze względu na prymarny charakter oryginalnej działalności formacji Mieczysława Szczuki. Działalność Praesensu nie została omówiona pomimo przyjętej cezury czasowej, ale wnikliwa i pod wieloma względami pionierska praca Rejniak-Majewskiej nie tylko tworzy szeroko zakreślone tło, ale przede wszystkim dowodzi znaczenia wizualnych kodów modernistów.

${ }^{10}$ Katalog I-ej Wystawy Architektury Nowoczesnej w Warszawie ułożony przez Jana Najmana i Lecha Niemojewskiego, „Blok” 1926, nr 11.

11 Jedno z nich przedstawiało Pawilon Turystyki, zaś drugie - betonowe drzewa zaprojektowane przez Roberta Mallet-Stevensa oraz rzeźbiarzy Jeana i Joëla Martel..

${ }^{12}$ Katalog I-ej Wystawy Architektury Nowoczesnej... dz. cyt., s. 2.

${ }^{13}$ M. L'Herbier, La Tête qui tourne, Belfond, Paris 1979 , s. 102.

${ }^{14}$ B. et S. B. [B. et S. Brukalscy], Dom wybudowany wedtug projektu Barbary Brukalskiej (Praesens) $i$ arch. Stanisława Brukalskiego (SAP, Praesens), „Dom. Osiedle. Mieszkanie” 1930, nr 1, s. 5.

${ }^{15}$ [Projekt i fotografia drzwi], „Praesens” 1930, nr 2, s. 63.

${ }^{16}$ Katalog I-ej Wystawy Architektury Nowoczesnej $w$ Warszawie... dz. cyt., s. 2.

17 Tamże, s. 1.

${ }^{18}$ Le Corbusier, W strone architektury, tłum. T. Swoboda, Centrum Architektury, Warszawa 2012.

${ }^{19} \mathrm{~L}$. Niemojewski, Wnętrza architektoniczne pałaców stanisławowskich. Styl syntetyczny, Warszawa 1927, s. 7-8.

20 S. Syrkus, Fabrykacja osiedli, "Architektura i Budownictwo" 1928, nr 8, s. 301.

${ }^{21}$ C. Jencks, Le Corbusier - tragizm współczesnej architektury, tłum. M. Biegańska, Wydaw- 
nictwa Artystyczne i Filmowe, Warszawa 1982, s. 79.

22 S. Syrkus, dz.cyt.

${ }^{23}$ M. Leśniakowska, Oczy Le Corbusiera, w: Le Corbusier, dz. cyt., s. 24.

24 J.-L. Cohen, Le Corbusier Le Grand, Phaidon Press Limited, New York 2014.

${ }^{25}$ Cyt. Za: Ł. Biskupski, Kinofilia zaangażowana: Stowarzyszenie Miłośników Filmu Artystycznego "Start" $i$ upowszechnianie kultury filmowej w latach 30. XX w., Wydawnictwo Przypis, Łódź 2017, s. 60-61. https://depot.ceon.pl/bitstream/handle/123456789/16664/kinofilia.pdf?sequence $=1 \&$ is Allowed $=y \quad($ dostęp: 13.01.2020).

${ }^{26}$ Tamże.

${ }^{27}$ Analizę filmu można znaleźć w książce: Hans Richter. Die neue Wohnung. Architektur. Film. Raum, red. A. Janser, A. Rüegg, Lars Müller Publishers, Berlin 2001. W filmie pokazano także moskiewski apartamenthouse (A. Fufayev, 1927-1928), szwedzką restaurację zorganizowaną na wystawie krajowej w Sztokholmie (Gunnar Asplund, 1930), z USA Lovell House wiedeńczyka Richarda Neutry, z Hiszpanii Club Real Nautico w San Sebastian (Jose Manuel de Aizpurua, Joaquin Labayen, 1929-1930).

${ }^{28}$ Por. opis miasta skomponowanego z wieżowców w: Le Corbusier, dz. cyt., s. 106-112.

29 „Praesens" 1930, nr 2, s. 47-50.

30 [fotomontaż Polonia], "Architektura i Budownictwo" 1933 , nr 5, s. 163. W fotomontaż wkomponowano zdjęcia gmachu Zakładu Ubezpieczeń Społecznych (Romuald Gutt, Józef Jankowski, 1928-1931), domów własnych Bohdana Lacherta (1928-1929) oraz Barbary i Stanisława Brukalskich (1927-1928), willi przy ul. Chocimskiej (Lucjan Korngold, Henryk Blum, 1930-1932), Banku Gospodarstwa Krajowego (Rudolf Świerczyński, 1928-1931), Wytwórni Papierów Wartościowych (Antoni Dygat, 1925-1928), Centralnego Instytutu Wychowania Fizycznego (Edgar Norwerth, od 1928), żoliborskich domów ZUS (Stanisław Brukalski i Józef Szanajca, 1930-1935), Gmachu Poczt i Telegrafów w Warszawie (Julian Puterman i Antoni Miszewski, 1928-1934).

${ }^{31}$ G. Jonkajtys-Luba, Brukalski Stanisław [biogram], w: Warszawska Szkoła Architektury 1915-1965, praca zbiorowa, Wydział Architektury Politechniki Warszawskiej, Warszawa 1967, s. 237.

32 Kronika, "Architektura i Budownictwo" 1933, nr 2, s. 60 .
${ }^{33}$ P. Rypson, Nie gęsi. Polskie projektowanie graficzne 1919-1945, Karakter, Kraków 2011, s. 57.

${ }^{34}$ Projekt Rennera zainspirowały typograficzne eksperymenty związanego z Bauhausem Herberta Bayera. W charakterystyce kroju Futura podnosi się geometrię oraz funkcjonalizm wynikający z pozbawionej dekoracji prostej formy. Zob. C. Burke, Paul Renner: The Art of Typography, Princeton Architectural Press 1998, s. 100.

35 J. Chmielewski, S. Syrkus, Warszawa funkcjonalna. Przyczynek do urbanizacji regionu warszawskiego, Centrum Architektury, Warszawa 2013.

${ }^{36}$ Por. S. Giedion, Przestrzeń, czas i architektura, tłum. J. Olkiewicz, Państwowe Wydawnictwo Naukowe, Warszawa 1968, s. 667-669.

${ }^{37}$ Le Corbusier, Karta ateńska, tłum. T. Swoboda, K. Szeronos, Centrum Architektury, Warszawa 2017.

${ }^{38}$ Kongres architektów (Architects' Congress, reż. László Moholy-Nagy, 1933), https://vimeo.com/283726259 (dostęp: 13.01.2020).

${ }^{39}$ Zob. P. Kubas, Sąd w teatrze. Dokumentalność reportażu scenicznego "Boston" w Studiu Teatralnym im. Stefana Żeromskiego, http://www.grotow-ski.net/perf-or_mer/performer-16/sad-w-teatrze-dokumentalnosc (dostęp: 13.01.2020).

${ }^{40}$ Na temat Bostonu zob.: S. Syrkus, Teoria, „Boston: biuletyn informacyjny Studio Teatralnego im. Stefana Żeromskiego" 1933, s. 1-2; R. Węgrzyniak, Procesy doktora Weicherta, Państwowy Instytut Wydawniczy, Warszawa 2017; K. Duniec: Dwudziestolecie. Przedstawienia, Instytut Teatralny im. Zbigniewa Raszewskiego, Instytut Sztuki PAN, SWPS, Warszawa 2017.

${ }^{41}$ S. Syrkus, Nuova teoria di theatro, „,Quadrante: Rivista Mensile" 1934, nr 11, s. 36.

${ }^{42}$ Rozmowa o "Bostonie", ,Tygodnik Ilustrowany" 1933, nr 26, s. 519.

43 J. Piłatowicz, Szymon Piotr Syrkus, https://www.ipsb.nina.gov.pl/a/biografia/szymon-piotr-syrkus (dostęp: 3.04.2020).

${ }^{44}$ Zob. M. Talarczyk-Gubała, Wanda Jakubowska. Od nowa, Wydawnictwo Krytyki Politycznej, Warszawa 2015, s. 158-164.

${ }^{45}$ Zob. Archipelag CIAM. Listy Heleny Syrkus, red. A. Kędziorek, K. Uchowicz, M. Wirkus, Narodowy Instytut Architektury i Urbanistyki, Warszawa 2019, s. 393-394.

46 S. Syrkus, Tempo architektury, "Praesens” 1930, nr 2, s. 32. 


\begin{abstract}
Katarzyna Uchowicz

Historyczka sztuki; zatrudniona w Instytucie Sztuki Polskiej Akademii Nauk w Pracowni Dokumentacji Architektury XX w. Obszar jej zainteresowań badawczych obejmuje architekturę XX w., interdyscyplinarną kulturę modernizmu, środowisko artystyczne awangardy oraz powojenną twórczość eksperymentalną. Kuratorka wystawy Awers/rewers. Architekt Bohdan Lachert (Muzeum Architektury we Wrocławiu), współautorka ekspozycji Algorithmen der Modernität (Instytut Polski w Berlinie). Autorka publikacji: Eternity and a Moment. 1918-1939 - Architecture as a Tool in Constructing Polish National Identity (2017), Ariergarda modernizmu. Katalog projektóco i realizacji Bohdana Lacherta $i$ fózefa Szanajcy (2017), Awers/rewers. Architekt Bohdan Lachert (2018), redaktorka (wspólnie z A. Kędziorek i M. Wirkus) pracy Archipelag CIAM. Listy Heleny Syrkus (2019). Prowadzi wykłady poświęcone historii i teorii architektury oraz planowaniu przestrzennemu XX w. na warszawskiej Akademii Sztuk Pięknych.
\end{abstract}

\section{Bibliografia}

Biskupski, Ł. (2017). Kinofilia zaangażowana: Stowarzyszenie Miłośników Filmu Artystycznego „Start” i upowszechnianie kultury filmowej w latach 30. XX w. Łódź: Wydawnictwo Przypis.

Chmielewski, J., Syrkus, S. (2013). Warszawa funkcjonalna. Przyczynek do urbanizacji regionu warszawskiego. Warszawa: Centrum Architektury.

Cohen, J.-L. (2014). Le Corbusier Le Grand. New York: Phaidon Press Limited.

Duniec, K. (2017). Dwudziestolecie. Przedstawienia. Warszawa: Instytut Teatralny im. Zbigniewa Raszewskiego, Instytut Sztuki Polskiej Akademii Nauk.

Giedion, S. (1968). Przestrzeń, czas i architektura (tłum. J. Olkiewicz). Warszawa: Państwowe Wydawnictwo Naukowe.

Jencks, C. (1982). Le Corbusier - tragizm wspótczesnej architektury (tłum. M. Biegańska). Warszawa: Wydawnictwa Artystyczne i Filmowe.

Kędziorek, A., Uchowicz, K., Wirkus, M. (red.) (2019). Archipelag CIAM. Listy Heleny Syrkus. Warszawa: Narodowy Instytut Architektury i Urbanistyki.

Kubas, P. (2018). Sąd w teatrze. Dokumentalność reportażu scenicznego "Boston” w Studiu Teatralnym im. Stefana Żeromskiego. Grotowski.net. http://www.grotowski.net/performer/performer-16/sadw-teatrze-dokumentalnosc

Le Corbusier (2012). W strone architektury (tłum. T. Swoboda). Warszawa: Centrum Architektury.

Minorski, J. (1970). Polska nowatorska myśl architektoniczna w latach 1918-1939. Warszawa: Wydawnictwo Naukowe PWN.

Piłatowicz, J. (2009). Syrkus Helena z Eliasbergów. W: A. Romanowski (red.), Polski słownik biograficzny (t. 46, s. 288). Warszawa - Kraków: Instytut Historii Polskiej Akademii Nauk.

Rejniak-Majewska, A. (2017). Obraz zwielokrotniony. Reprodukcja fotograficzna i wizualne narracje sztuki awangardowej 1910-1939. Łódź: Wydawnictwo Uniwersytetu Łódzkiego.

Rypson, P. (2011). Nie gęsi. Polskie projektowanie graficzne 1919-1945. Kraków: Karakter.

Talarczyk-Gubała, M. (2015). Wanda Jakubowska. Od nowa. Warszawa: Wydawnictwo Krytyki Politycznej.

Węgrzyniak, R. (2017). Procesy doktora Weicherta. Warszawa: Państwowy Instytut Wydawniczy. 


\begin{tabular}{|c|c|}
\hline $\begin{array}{r}\text { Keywords: } \\
\text { modernism; } \\
\text { architecture of } 20^{\text {th }} \\
\text { century; } \\
\text { Praesens; } \\
\text { spacetime; } \\
\text { synthesis of the } \\
\text { arts; } \\
\text { design of } \\
\text { movement }\end{array}$ & $\begin{array}{l}\text { Abstract } \\
\text { Katarzyna Uchowicz } \\
\text { The Designers of Spacetime. Modernist Architecture in Film } \\
\text { The article discusses selected inter-war artistic projects in which } \\
\text { architecture and film intersect. The activity of the group of moder- } \\
\text { nist artists called Praesens serves as a starting point for a presen- } \\
\text { tation of modernism as both a synthesis of the arts and as a space } \\
\text { of interdisciplinary artistic dialogues. Several issues are addressed } \\
\text { here to capture the relations between film and architecture, namely: } \\
\text { the involvement of architects in stage design (as exemplified by Szy- } \\
\text { mon Syrkus and Andrzej Pronaszko), collaboration between archi- } \\
\text { tects and film directors (Robert Mallet-Stevens, Marcel L'Herbier), } \\
\text { the production of photomontages, the practice of modelling stage } \\
\text { designs on architecture as well as designing architectural structures } \\
\text { inspired by stage designs. Another question discussed is the new } \\
\text { language of architecture exemplified by such terms as the design of } \\
\text { movement or 'spacetime? These terms drawn from the language of } \\
\text { the film were both commonly used by architects and widely com- } \\
\text { mented on by Ricciotto Canudo, an Italian theoretician of cinema. } \\
\text { Moreover, this paper recalls the biographies of architects who, after } \\
\text { having graduated in architecture, devoted their lives and careers to } \\
\text { stage design entering a new field of artistic activity }\end{array}$ \\
\hline
\end{tabular}

